\title{
EFEKTIVITAS UNDANG-UNDANG LALU LINTAS DAN ANGKUTAN JALAN MEMINIMALISIR FATALITAS KECELAKAAN LALU LINTAS
}

\section{Effectiveness of the UU LLAJ to Minimizing the Fatality Traffic Accident}

\author{
Nurhasan Ismail \\ Fakultas Hukum, Universitas Gajah Mada \\ Jl. Sosio Yustisia Bulaksumur No. 1 Bulaksumur \\ Caturtunggal, Depok, Sleman, DI Yogyakarta \\ nurhasanw@yahoo.com
}

\begin{abstract}
Traffic accidents are one of the main problems of road users. Therefore various ways are done to suppress the number of accidents, especially the number of casualties that occur on the highway. UU no. 22 Tahun 2009 is a legal instrument that is responsible for the implementation of the purpose of traffic (road) is safe and friendly for its users. Legal instruments need to be supported by various supporting instruments and norms and ethics in the application carried out in the community, such as socialization and education of traffic. It is, therefore, necessary to examine the effectiveness of these legal instruments against the limbal fatalities.
\end{abstract}

Keywords: traffic accident, road safety, legal instrument, legal instrument effectivity, regulation

\begin{abstract}
Abstrak
Kecelakaan lalu lintas merupakan salah satu permasalahan utama para pengguna jalan. Oleh karena itu berbagai cara dilakukan untuk menekan angka kecelakaan terutama jumlah korban yang terjadi di jalan raya. UU No. 22 Tahun 2009 merupakan instrumen hukum yang bertanggungjawab atas terlaksananya tujuan lalu lintas (jalan) yang aman dan ramah bagi penggunanya. Instrumen hukum perlu didukung berbagai instrumen pendukung dan norma serta etika dalam penerapan yang dilakukan di masyarakat seperti sosialisasi dan pendidikan lalu lintas. Oleh karena itu perlu pengujian terhadap efektitas instrumen hukum tersebut terhadap fatalitas lakalintas.
\end{abstract}

Kata kunci: kecelakaan lalu lintas, keselamatan jalan, instrumen hukum, efektivitas instrumen hukum, peraturan

\section{PENDAHULUAN}

Pembentukan suatu produk legislasi dimaksudkan untuk mewujudkan suatu kepentingan tertentu sebagai tujuannya. UU No.22 Tahun 2009 sebagai pengganti UU No.14 Tahun 1992 dimaksudkan untuk mewujudkan lalu lintas dan angkutan jalan yang aman, selamat, tertib, dan lancar. Setiap pengguna jalan baik dengan maupun tanpa kendaraan mengharapkan kondisi aman yakni terbebasnya diri dari ancaman tindak kejahatan atau kerusuhan sosial selama berlalu lintas. Pengguna jalan juga menginginkan perjalanan berlalu lintasnya selamat yakni tidak adanya kecelakaan yang melibatkan dirinya sehingga sampai di tempat tujuan dengan selamat. Kelancaran berlalu lintas menjadi dambaan dari setiap pengguna jalan, dalam pengertian selama berlalu lintas tidak dihadapkan pada hambatan-hambatan baik yang berupa kepadatan lalu lintas yang mengarah pada kemacetan atau berupa kondisi ketidaklaikan fungsi jalan. Suatu harapan lain adalah 
terkondisikannya berlalu lintas yang tertib di mana setiap pengguna jalan mematuhi semua marka, rambu, alat pemberi isyarat lalu lintas, dan pengaturan lalu lintas oleh petugas.

Terciptanya keamanan, keselamatan, ketertiban, dan kelancaran (KAMSELTIBCAR) berlalu lintas merupakan tujuan antara (transitional goal) dalam rangka terwujudnya tujuan akhir (final goal). Tujuan akhir yang diharapkan dapat diujudkan yaitu : (1) mendorong perekonomian nasional. Artinya terciptanya Kamseltibcar lalu lintas diharapkan arus pengangkutan dan distribusi barang atau produk industri berlangsung dengan aman, selamat, tertib, dan lancar sehingga aktivitas perekonomian baik di lokasi proses produksi dilakukan maupun di lokasi perdagangan produksi terus berkembang; (2) memajukan kesejahteraan umum atau masyarakat baik secara materiil maupun immateriil. Secara materiil, kesejahteraan masyarakat berupa pemenuhan kebutuhan pokok terutama sandang, papan, dan pangan. Pemenuhan kebutuhan pokok dapat diupayakan jika barang kebutuhan pokok dalam jumlah yang cukup dapat terdistribusi dan sampai ke tangan masyarakat. Secara immateriil, kesejahteraan berupa perasaan aman dan selamat khususnya selama berlalu lintas. Masyarakat tidak dihadapkan pada "image" lalu lintas yang diwarnai dengan kecelakaan lalu lintas dengan korban luka parah atau meninggal dunia. Perasaan aman dan selamat tercipta jika jalan dengan lalu lintasnya tidak menjadi "killing field"; (3) memperkukuh ikatan persatuan bangsa, dalam pengertian bahwa lalu lintas dan angkutan jalan yang berlangsung dengan kamseltibcar akan berpengaruh pada tingkat mobilitas penduduk antar wilayah semakin tinggi. Mobilitas yang tinggi akan menciptakan interaksi sosial antar etnis atau kelompok masyarakat yang berasal dari wilayah yang berbeda akan berlangsung dengan baik. Kondisi sosial demikian tentu secara potensial akan membangun ikatan sosial sebagai satu bangsa yang semakin kuat.

Tujuan transisi/antara dan tujuan akhir dengan sangat jelas tercermin dalam Pasal 3 UU No.22 Tahun 2009. Intinya, di satu sisi UU LLAJ menghendaki adanya keamanan, keselamatan, ketertiban, dan kelancaran dalam aktivitas lalu lintas dan angkutan jalan, sedangkan di sisi lain diharapkan UU ini berkontribusi pada perkembangan pembangunan perekonomian dan kesejahteraan umum serta memperkuat integrasi nasional. Logika hukum yang dapat dibangun dari ketentuan Pasal 3 tersebut bahwa pencapaian lalu lintas dan angkutan jalan yang aman, selamat, tertib, dan lancar diharapkan akan berimplikasi pada perekonomian negara, kesejahteraan masyarakat, dan integrasi kehidupan berbangsa.

Logika hukum di atas memberikan landasan sebuah cita-cita bahwa lalu lintas dan angkutan jalan pasca berlakunya UU No.22 Tahun 2009 tidak lagi menjadi faktor penyebab penghambat bagi kelancaran pengangkutan dan distribusi barang-barang baik hasil produksi kebutuhan masyarakat dan bahan kebutuhan industri maupun hasil produksi yang akan diekspor dan distribusi barang impor. Pasca berlakunya UU LLAJ tidak ada lagi penilaian bahwa kemacetan dan kecelakaan lalu lintas terutama di kota-kota besar di Indonesia telah menimbulkan kerugian potensial ekonomis mencapai trilyunan rupiah.

Pasca berlakunya UU LLAJ diharapkan jalan raya tidak menjadi arena yang menimbulkan perasaan dikotomis yaitu mengasikkan namun juga menakutkan sebagai killing field bagi para pengguna jalan. Begitu juga diharapkan lalu lintas dan angkutan jalan tidak menjadi faktor pencipta fenomena kelaparan atau kekurangan kebutuhan pokok di wilayah-wilayah tertentu karena terhambatnya pengangkutan barang kebutuhan pokok masyarakat. Penilaian bahwa jalan berfungsi juga sebagai killing field akan semakin berkurang dan dicita-citakan menjadi terkurangi, syukur jika mencapai angka nol atau zero accident melalui penciptaan LLAJ yang aman, selamat, tertib, dan lancar. 
Ke depan, lalu lintas dan angkutan jalan juga berkontribusi pada penciptaan intensitas interaksi sosial antar kelompok komponen bangsa Indonesia. Terciptanya jaringan lalu lintas dan angkutan jalan yang semakin meluas akan mendukung terjadinya intensitas interaksi sosial antar kelompok etnis sehingga tercipta bangunan perasaan ikatan kebangsaan dan tersubordinasikannya ikatan etnis terhadap ikatan kebangsaan. Kontribusi LLAJ pada penguatan ikatan kebangsaan akan mengurangi konflik etnis yang sering mewarnai perjalanan kehidupan berbangsa.

\section{INSTRUMENTASI HUKUM}

Mencermati tujuan transisi/antara dan tujuan akhir sebagaimana diuraikan di atas yang dibebankan pada UU LLAJ untuk mengemban 2 (dua) fungsi hukum sekaligus yaitu sebagai alat kontrol sosial dan alat rekayasa sosial (Rahardjo, 1989). Fungsi kontrol sosial hukum merupakan fungsi konvensional dalam rangka mewujudkan keteraturan atau ketertiban hubungan sosial di antara warga masyarakat. Fungsi kontrol sosial juga dimaksudkan agar di antara warga masyarakat tidak terjadi konflik kepentingan yang akan menyebabkan kekacauan sosial. Jika terdapat perilaku yang menyimpang, para pelakunya harus diberi sanksi yang tegas dengan tujuan agar terdapat efek jera. Kejeraan sangat diperlukan untuk mencegah pengulangan perilaku yang menyimpang.

Sebaliknya, fungsi rekayasa sosial merupakan fungsi modern dalam rangka mewujudkan kondisi sosial, ekonomi, dan politik tertentu sesuai yang dicita-citakan melalui penggunaan hukum. Setiap masyarakat modern membangun cita-cita dari setiap bidang kehidupannya yang diupayakan untuk diujudkan. Upaya pencapaiannya diserahkan kepada peranan negara melalui pembentukan dan pelaksanaan undang-undang. Fungsi rekayasa sosial lebih diarahkan untuk merubah perilaku setiap orang mengarah pada kondisi sosial-ekonomipolitik yang dicita-citakan. Disinilah fungsi pelayanan pelaksana atau penegak hukum sangat dituntut, bahkan pemberian insentif materiil ataupun immateriil menjadi instrumen utama. Setiap pelanggaran terhadap norma berperilaku tidak harus direspon dengan pemberian sanksi namun dapat juga dengan pengutamaan pemberian bimbingan dan penyadaran arti penting dari kondisi sosial-ekonomi-politik yang dicita-citakan di masa yang akan datang.

Dalam kedudukannya sebagai alat kontrol sosial, UU LLAJ harus mampu mengarahkan perilaku baik para pengguna lalu lintas maupun aparat atau petugas yang terkait dengan lalu lintas agar sesuai dengan pedoman berperilaku yang ada dalam UU tersebut. Para pengguna jalan harus diarahkan untuk mematuhi semua rambu-rambu lalu lintas, marka jalan, alat pemberi isyarat lalu lintas, dan pengaturan lalu lintas oleh petugas. Tujuannya adalah agar tercipta keteraturan, ketertiban, dan kelancaran berlalu lintas. Arus gerak kendaraan dan orang serta perpindahan barang dan/atau orang dari satu tempat ke tempat yang lain dengan menggunakan kendaraan di ruang lalu lintas jalan berlangsung secara tertib, teratur, dan lancar. Kepentingan antara pengguna jalan yang satu dengan lainnya tidak saling bertentangan yang disebabkan oleh ketidakteraturan atau ketidaktertiban atau ketidaklancaran lalu lintas.

Para aparat pelaksana/penegak UU LLAJ diarahkan untuk mematuhi peranan dan tanggungjawab yang sudah dinormakan. Terhadap setiap pelanggaran lalu lintas dan angkutan jalan, para petugas mampu bertindak tegas dalam rangka mendorong kepatuhan pengguna jalan. Aparat tidak boleh melakukan pemberian legitimasi atau pembenaran terhadap setiap pelanggaran dengan cara pengenaan denda. Pengenaan denda terhadap 
pelanggaran daya muat kendaraan bermotor berupa kelebihan muatan harus diikuti dengan penyitaan atas barang kelebihan muatan. Jika barang kelebihan muatan tidak disita berarti telah terjadi pengesahan atas pelanggaran dengan cara membayar denda. Denda merupakan satu bentuk sanksi yang dijatuhkan terhadap pelanggaran dan bukan bentuk pengesah atas keberlangsungan pelanggaran yang terjadi.

Dalam kedudukannya sebagai alat rekayasa sosial terutama mewujudkan sebuah cita-cita meminimalisir fatalitas lakalantas atau bahkan "zero-accident" sebagai bentuk immaterill dari tujuan kesejahteraan umum/ masyarakat, UU LLAJ tidak hanya cukup mengarahkan para pengguna jalan untuk berperilaku patuh namun yang lebih mendasar harus dapat merubah sikap dan perilaku mereka dan kita semua dalam berlalu lintas. Perubahan sikap dan perilaku yang dikehendaki adalah jalan bukanlah arena berlangsungnya killing field, jalan bukanlah sarana ugal-ugalan berkendaraan, jalan bukanlah arena unjuk "inilah daku sebagai orang yang paling terampil berkendaraan". Berlalu lintas di jalan bukanlah hanya sekedar mematuhi rambu/marka/APIL/petugas namun harus mendasarkan pada etika moral berlalu lintas berupa sikap saling menghormati sesama pemakai jalan, sikap dan perilaku untuk tidak menyakiti perasaan sesama pengguna jalan, sikap dan perilaku yang menempatkan ruang lalu lintas sebagai ruang umum/publik di mana kita tidak boleh berperilaku sekehendak keinginan kita, ruang lalu lintas bukan ruang pribadi yang dapat berperilaku sekehendak keinginan kita, sikap dan perilaku kita berlalu lintas tidak boleh menempatkan pengguna jalan yang lain berada dalam kondisi ketidaknyamanan/ kekagetan luar biasa. Nilai yang sudah tertanam bahwa berkendaraan lebih cepat lebih baik harus diubah dengan "biar tidak terlalu cepat namun yang penting aman dan selamat".

Untuk mewujudkan suatu kondisi sosial baru yaitu perubahan sikap dan perilaku para pengguna jalan yang mengarah pada meminimalisir fatalitas lakalantas atau bahkan zeroaccident perlu adanya tanggungjawab dan peranan aparat pelaksana UU LLAJ. Setiap tindakan aparat pelaksana UU harus diarahkan pada pemberian pelayanan yang optimal dan sekaligus sebagai media melakukan pendidikan membangun etika moral berlalu lintas. Di antaranya adalah :

1. Pemberian pelayanan uji/service berkala kendaraan bermotor atau uji pemberian Surat Ijin Mengemudi di samping sebagai sarana akumulasi pendapatan negara dan optimalisasi kepuasan pemberian pelayanan, juga harus dalam membangun etika moral berlalu lintas tersebut. Jika kendaraan yang diuji atau diservice baik di Instansi Penguji maupun di Bengkel Umum Kendaraan Bermotor tidak memenuhi syarat kelaikan kendaraan bermotor harus dinyatakan atau disampaikan dengan tegas kepada pemilik. Khusus untuk Bengkel Umum Kendaraan Bermotor harus dikembangkan kewajiban untuk melaporkan secara berkala mengenai kondisi kendaraan yang diservice kepada Dinas Perhubungan. Begitu juga, calon pengemudi kendaraan bermotor yang meminta SIM harus memenuhi syarat-syarat yang sudah ditentukan termasuk pelaksanaan ujian harus dimaksudkan untuk menanamkan etika moral;

2. Penjagaan atau pengawasan petugas (polisi lalu lintas atau LLAJ) secara rutin harian ataupun dalam rangka pemeriksaan kendaraan bermotor di jalan baik yang bersifat eksidental maupun berkala harus diarahkan untuk mendorong perubahan sikap dan perilaku pengguna jalan seperti di atas. Keberadaan petugas di jalan tidak selalu mencari kesalahan atau pelanggaran yang kemudian dilakukan tindakan penilangan dan pembayaran denda ataupun gratifikasi. Kehadiran petugas harus berfungsi sebagai "pengayom" bagi warga masyarakat pengguna jalan. Jika pengendara/pengemudi menjalankan kendaraan bermotornya secara tidak wajar, maka petugas menghentikan 
bukan untuk ditilang dan didenda namun untuk mengingatkan agar berlalu lintas yang wajar sehingga tidak membahayakan sesama pengguna jalan. Jika terdapat kendaraan bermotor yang alat perlengkapannya secara nyata terlihat tidak lengkap atau tidak berfungsi, maka petugas menghentikan untuk mengingatkan agar perlengkapan kendaraan bermotor itu dilengkapi dan difungsikan demi keamanan dan keselamatan pengemudi dan penumpangnya.

3. Pengawasan terhadap kondisi jalan yang fungsinya tidak laik harus dilakukan secara rutin dalam rangka memelihara kelaikan fungsi jalan. Jika pengawasan dilakukan langsung oleh petugas dari lingkungan Departemen Pekerjaan Umum untuk jalan nasional atau dari lingkungan Kantor Dinas pekerjaan umum daerah untuk jalan daerah atau desa, maka kondisi jalan yang fungsinya tidak laik harus segera dilakukan pengembalian fungsinya. Jika kondisi ketidaklaikan fungsi jalan diketahui oleh petugas polisi lalu lintas atau petugas LLAJ, maka hendaknya segera dikoordinasikan kepada instansi yang bertanggungjawab atas pemeliharaan jalan yang bersangkutan.

\section{MELAKSANAKAN UU LLAJ SEBAGAI SUATU SISTEM}

Kalau minimalisasi fatalitas lakalantas atau bahkan zero-accident sebagai perujudan kesejahteraan immateriil masyarakat di bidang lalu lintas ditempatkan sebagai tujuan akhir yang hanya dapat dicapai melalui rekayasa perubahan sikap dan perilaku, pertanyaannya adalah mampukah UU No.22 Tahun 2009 mendorong perubahan sikap dan perilaku baik para pengguna jalan maupun petugas di semua sektor yang terkait dengan lalu lintas dan angkutan jalan?

UU LLAJ sebagai satu bentuk dari hukum hanya berisi ketentuan yang terumuskan sebagai benda mati atau berisi norma yang bersifat pasif (Mertokusumo, 1999). Artinya dengan disahkan dan diberlakukan UU LLAJ secara otomatis lalu lintas dan angkutan jalan akan berlangsung dengan tertib dan lancar serta akan tercipta lalu lintas yang menjamin keamanan dan keselamatan. Dengan demikian akan secara otomatis minimalisasi fatalitas lakalantas atau bahkan zero-accident tercipta atau peranan jalan sebagai killing field akan dengan sendirinya berkurang seminimal mungkin. UU LLAJ hanyalah rumusan norma yang masih bersifat das sollen atau masih berstatus sebagai law as it should be yaitu hukum yang masih berada dalam tataran cita-cita atau keinginan dan serba mengharuskan.

UU LLAJ sebagai instrumen yang pasif hanyalah berkedudukan sebagai salah satu unsur atau komponen dari sistem hukum. Dalam ranah literatur, hukum merupakan suatu sistem yang komponen atau unsur-unsurnya terdiri dari : Substansi Normanya, Struktur Kelembagaan Pelaksananya, dan Budaya Hukum (Friedman, 1975). Artinya upaya untuk mewujudkan perubahan sikap dan perilaku berlalu lintas yang menjamin minimalisasi kecelakaan, syukur ke arah zero-accident tergantung pada kondisi masing-masing komponen sistem hukum lalu lintas dan angkutan jalan serta upaya mensinerjikan ketiganya ke arah penciptaan perubahan tersebut.

Untuk itu perlu dilakukan penilaian atas ketiga komponen sistem hukum mengenai potensi dukungannya untuk mendorong terjadinya perubahan ke arah minimalisasi fatalitas lakalantas atau bahkan zero-accident, yaitu : 


\section{Substansi Undang-Undang Nomor 22 Tahun 2009}

Potensi dukungan substansi UU dapat dinilai dari 2 (dua) aspek yaitu komprehensivitas normanya dan kekonsistenan norma mendorong terujudnya tujuan. UU No.22/2009 dibentuk dengan mengakomodasi 326 pasal yang dibagi ke dalam XXII bab. Dari 22 bab terdapat 12 bab yang dirinci menjadi bagian-bagian yang berjumlah 68 bagian. Substansi yang diatur di dalamnya mencakup : (a) tujuan yang hendak dicapai baik tujuan transisi maupun tujuan akhir; (b) aspek manusia baik sebagai pengguna jalan maupun sebagai pembina dan penyelenggara lalu lintas termasuk di dalamnya penegakan hukum; (c) kendaraan sebagai alat berlalu lintas dan angkutan jalan baik yang terkait dengan aspek teknis-fisik kendaraan maupun aspek administratif sebagai pendukung utamanya; (d) sarana dan prasarana lalu lintas dan angkutan jalan seperti ruang lalu lintas, jalan beserta pendukungnya, terminal, halte, tempat parkir, rambu/marka/APIL; (e) tatacara berlalu lintas yang diatur begitu rinci; (f) kontrol atas kepadatan lalu lintas baik yang bersifat preventif seperti keharusan adanya Analisis Dampak Lalu Lintas (ANDALALIN) dari setiap pembangunan pusat kegiatan maupun bersifat represif seperti rekayasa petugas lalu lintas untuk mengurangi kepadatan; (g) tanggungjawab pemilik/perusahaan angkutan seperti jam kerja pengemudi; (h) sanksi baik keperdataan maupun administratif dan pidana.

Dengan mencermati substansi yang tertuang dalam UU LLAJ ini, tingkat komprehensivitas normanya sudah diupayakan sedemikian tingginya. Tampaknya tidak ada lagi yang terlupakan mengenai aspek-aspek berlalu lintas dan angkutan jalan yang belum diatur dalam UU ini. Semua aspek sudah teridentifikasi dan terumuskan dalam pasal-pasal. Sedemikian komprehensifnya substansi UU LLAJ ini sampai terdapat penilaian secara teoritis-akademis bahwa : politik pembangunan hukum Indonesia sudah tidak lagi sepenuhnya mengikuti arus pembentukan undang-undang dari civil law system yang cenderung undang-undang hanya mengatur norma-norma dasarnya saja namun sudah bergeser pada arus common law system seperti yang dianut Inggeris dan negara-negara Anglo-Saxon lainnya yang sudah mengatur secara rinci di tingkatan undang-undang. Penilaian lainnya bahwa negara sudah sedemikian intervensionis mengatur semua perilaku orang di jalan sedemikian mendalam sehingga tidak ada ruang kebebasan orang di jalan, namun sikap intervensionis negara dalam pengaturan lalu lintas dan angkutan jalan ternyata memang diperlukan.

Namun pertanyaannya adalah apakah tingkat komprehensivitas substansi UU LLAJ yang begitu tinggi mampu mendukung tercapainya tujuan transisi yaitu KAMSELTIBCAR dan tujuan akhir yaitu meminimalisir kecelakaan dan korban manusia dan jangka panjangnya zero-accident? Melalui analisis deduktif yaitu mengidentifikasi perilaku yang ingin didorong tercipta oleh setiap norma, kita dapat melakukan penilaian potensi dukungan norma terhadap pencapaian tujuan. Untuk itu perlu diuraikan secara singkat analisis deduktif terhadap beberapa norma untuk menunjukkan ada-tidaknya potensi dukungan tersebut, yaitu :

\section{Norma Berkenaan Dengan Perilaku Pengguna Jalan}

Pengguna jalan adalah perorangan yang berlalu lintas di jalan baik dengan menggunakan kendaraan bermotor dan kendaraan tidak bermotor maupun hanya berjalan kaki. UU LLAJ sudah menetapkan ketentuan yang berlaku bagi masing-masing kelompok pengguna jalan, yang di antaranya : (1) tempat berlalu lintas yaitu pejalan kaki harus berjalan di tempat (trotoar) yang disediakan dan ketika hendak menyeberang jalan harus di tempat penyeberangan dan jika tidak tersedia maka menyeberanglah dengan penuh kehati-hatian, 
kendaraan tidak bermotor dan kendaraan bermotor yang tingkat kecepatannya lebih rendah (sepeda motor) harus berlalu lintas di lajur jalan yang paling kiri, sedang kendaraan bermotor yang kemampuan kecepatannya lebih tinggi berlalu lintas di lajur sebelah kanan; (2) persyaratan mengemudi/mengemudi kendaraan bermotor, yaitu harus mempunyai Surat Izin Mengemudi (SIM) yang untuk memperolehnya harus mempunyai keterampilan mengemudi, kejiwaan yang matang, dan lulus ujian teori peraturan dan praktik yang ditentukan sedemikian ketat. Bahkan untuk pengemudi kendaraan bermotor angkutan umum harus mengikuti pendidikan mengemudi yang dilakukan secara khusus sebelum memohon SIM; (3) batasan jam kerja mengemudi terutama bagi pengemudi kendaraan bermotor angkutan umum. Pengemudi merupakan manusia dengan semua keterbatasannya yang tentu mengalami kelelahan setelah melampaui batas kemampuannya. Oleh karenanya melalui batasan jam kerja diharapkan pengemudi tidak mengalami kelalahan sehingga tidak mengarah pada potensi terjadinya kecelakaan.

Ketentuan-ketentuan di atas di samping dimaksudkan untuk mendorong munculnya perilaku yang tertib dan lancar berlalu lintas, juga agar para pengguna jalan selamat terhindar dari kecelakaan yang berpotensi mengancam jiwanya sendiri maupun orang lain. Dengan berjalan kaki di trotoar dan menyeberang di tempat penyeberangan, pejalan kaki tidak mengganggu arus lalu lintas di badan jalan dan hal itu dimaksudkan untuk terjamin dan terlindunginya kepentingan keselamatan diri dan pengguna jalan lainnya. Dengan keharusan kendaraan yang lebih rendah kecepatannya berjalan di lajur sebelah kiri dan yang lebih tinggi kecepatannya di lajur sebelah kanan dimaksudkan agar antara kedua kelompok kendaraan tersebut tidak saling mengganggu dan sekaligus mencegah terjadinya kecelakaan karena adanya perbedaan kecepatan. Begitu juga keharusan mempunyai SIM dengan persyaratan yang ketat dimaksudkan agar pengemudi kendaraan bermotor sungguh-sungguh mempunyai tingkat keterampilan mengemudi yang baik dengan tingkat kejiwaan yang matang sehingga perilaku mengemudinya wajar dan tidak membahayakan lalu lintas yang berpotensi pada terjadinya kecelakaan.

\section{Norma Berkenaan Dengan Perilaku Pembina dan Penyelenggara LLAJ}

Pembina dan penyelenggara lalu lintas dan angkutan jalan adalah lembaga yang kinerjanya direpresentasikan oleh perilaku individu-individu yang diberi otoritas atau kewenangan di masing-masing lembaga baik yang ada di tingkat pusat maupun daerah. Di tingkat pusat, pembinaan dan penyelenggaraan LLAJ terdistribusi pada Ditjen Perhubungan Darat Dephub, Ditlantas Polri, Departemen Pekerjaan Umum, dan Departemen Perindustrian. Pembinaan dan penyelenggaraan LLAJ di daerah dilaksanakan oleh pemerintah daerah beserta dinas perhubungan dan kepolisian daerah/kepolisian resort.

Ketentuan yang diarahkan pada perilaku disiplin para petugas pembina dan penyelenggara sudah ditetapkan dalam UU LLAJ, yang di antaranya adalah : (1) penyusunan rencana jaringan jalan, letak lokasi terminal, desain jalan, lokasi parkir, di antaranya, harus didasarkan pada pertimbangan KAMSELTIBCAR lalu lintas; (2) pelaksanaan pengujian baik terhadap calon pengemudi maupun terhadap persyaratan teknis dan kelaikan kendaraan bermotor serta kelaikan fungsi jalan harus dilaksanakan sungguh-sungguh dalam rangka menjamin keamanan dan keselamatan LLAJ dan bukan didasarkan pada kepentingan akumulasi pendatapan negara semata; (3) pelaksanaan pengawasan terhadap keberlangsungan arus lalu lintas dan angkutan jalan harus ditujukan pada upaya membangun kesadaran berlalu lintas yang menjamin KAMSELTIBCAR dan bukan semata pada kepentingan masuknya uang denda serta mengabaikan menciptakan kejeraan para 
pengguna jalan yang berperilaku melanggar; (4) pemberian perijinan baik terhadap kegiatan usaha angkutan umum dengan trayek dan non trayek maupun terhadap kegiatan pembangunan yang berdampak pada tingkat kepadatan lalu lintas harus diorientasikan pada kepentingan menjaga KAMSELTIBCAR dan bukan kepentingan tawar-menawar kepentingan dan akumulasi pendapatan semata.

Semua ketentuan yang ditujukan kepada kedisiplinan petugas pembina dan penyelenggara dalam perencanaan, pengujian, pengawasan, dan perijinan di atas mengandung maksud terciptanya KAMSELTIBCAR berlalu lintas. Secara implisit dalam ketentuan tersebut terkandung semangat untuk mencegah terjadinya kecelakaan lalu lintas dan menghindari perubahan penggunaan jalan sebagai killing field.

\section{Norma Untuk Menjamin Persyaratan Teknis dan Kelaikan Kendaraan Bermotor}

Adanya persyaratan teknis dan kelaikan kendaraan bermotor dimaksudkan agar terdapat jaminan berlangsungnya lalu lintas yang tertib, lancar, aman, dan selamat. Kendaraan bermotor pada masyarakat modern merupakan sarana angkutan yang sangat dominan di jalan baik yang pribadi maupun umum. Dengan tingkat perkembangan teknologi otomatif yang semakin maju, kendaraan bermotor dirancang dengan kecepatan yang semakin tinggi. Semakin tinggi tingkat kecepatan kendaraan bermotor, semakin tinggi juga kontribusinya terhadap dinamika sosial ekonomi masyarakat. Namun di samping efek positifnya, kecepatan gerak kendaraan bermotor juga mempunyai dampak negatif yaitu tingkat bahaya akan terjadinya kecelakaan juga semakin tinggi dan berarti juga potensi korban nyawa manusia semakin tinggi.

Oleh karenanya, kendaraan bermotor yang digunakan berlalu lintas di jalan harus dirancang memenuhi persyaratan teknis dan kelaikan sehingga potensi terjadinya kecelakaan ditekan seminimal mungkin. UU LLAJ sudah mengakomodasi persyaratan tersebut, yang di antaranya adalah : (1) persyaratan teknis yang menyangkut keserasian antar sejumlah komponen utama seperti kerangka landasan, mesin penggerak dan sistem pembuangan, sistem roda dan supensi serta alat kemudi dan rem, ketersediaan komponen pendukung dan pelengkap seperti pengukur kecepatan, sabuk keselamatan atau helm dan rompi pemantul cahaya, dan keserasian ukuran kendaraan bermotor dengan fungsinya sebagai angkutan orang atau barang. Persyaratan teknis ini jelas dimaksudkan agar gerak maju kendaraan bermotor tidak mendatangkan potensi terjadinya kecelakaan; (2) persyaratan kelaikan jalan kendaraan bermotor yang menyangkut kesesuaian antara kecepatan maksimum mesin dengan sistem rem utama dan kincup roda depan, kesesuaian antara kinerja roda dengan kondisi ban, dan kesesuaian antara daya mesin penggerak dengan berat kendaraan. Persyaratan kelaikan jalan kendaraan bermotor dimaksudkan agar terdapat keseimbangan antara daya maksimum mesin penggerak yang mendorong kecepatan kendaraan dengan perlambatan atau penghentian kendaraan berlangsung secara aman dan selamat; (3) pengujian berkala kelaikan kendaraan bermotor yang berkaitan dengan pengawasan terhadap keberlangsungan kelaikan kendaraan bermotor untuk digunakan sebagai sarana angkutan. Pengujian ini dilakukan baik oleh instansi pemerintah yang diberi tugas penguji maupun oleh Agen Tunggal Pemegang Merek atau Bengkel Umum Kendaraan Bermotor. Ketentuan pengujian berkala ini dimaksudkan agar kondisi kendaraan bermotor tetap berada dalam kondisi laik jalan sehingga ketika digunakan berlalu lintas tetap dapat menjamin keselamatan dan keamanan baik bagi pengemudi dan penumpang maupun bagi pengguna jalan lainnya. 


\section{Norma Untuk Menjamin Kelaikan Fungsi Jalan}

Jalan umum merupakan sarana utama berlalu lintas dan ketersediaan jalan yang berfungsi dengan baik merupakan syarat bagi keberlangsungan lalu lintas yang aman, selamat, tertib, dan lancar. Oleh karena itu, UU LLAJ telah merumuskan ketentuan untuk menjamin ketersediaan dan keberlangsungan fungsi jalan yang laik, yaitu : (1) uji kelaikan fungsi jalan yang harus dilakukan baik sebelum jalan yang baru dibangun digunakan sebagai jalan umum maupun secara berkala terhadap jalan yang sudah digunakan sebagai sarana berlalu lintas. Uji kelaikan dimaksudkan untuk menjamin penggunaan jalan bagi terciptanya keamanan, keselamatan, ketertiban, dan kelancaran berlalu lintas; (2) perbaikan jalan yang menjadi kewajiban pemerintah/pemerintah daerah untuk melakukan terhadap setiap terjadi kerusakan jalan. Ketentuan ini dimaksudkan agar fungsi jalan yang laik dapat terus diperlihara sehingga kerusakan tidak semakin parah yang dapat menjadi penyebab terjadinya kecelakaan; (3) penyediaan dana reservasi jalan yaitu suatu upaya menghimpun dana yang dapat digunakan baik untuk memelihara kelaikan fungsi jalan maupun untuk membangun jalan yang berfungsi laik.

\section{Norma Yang Memberi Pedoman Tatacara Berlalu Lintas}

Perilaku setiap orang yang ada di jalan umum baik dengan menggunakan atau tanpa menggunakan kendaraan sangat menentukan keselamatan, ketertiban, dan kelancaran lalu lintas. Oleh karenanya UU LLAJ merumuskan dengan lengkap mengenai tatacara berlalu lintas di jalan umum, yang di antaranya kewajiban-kewajiban untuk : (1) mengemudi dengan wajar dan berperilaku tertib dengan mematuhi rambu/marka/APIL/pengarahan petugas/batas kecepatan maksimal/penggunaan sabuk keselamatam/helm untuk mencegah terjadinya kecelakaan atau jatuhnya korban jiwa; (2) menyalakan lampu utama di siang hari bagi sepeda motor sebagai peringatan untuk hati-hati baik bagi pengendara dan pengguna jalan lainnya; (3) menggunakan jalur dan lajur yang sudah ditentukan pada waktu berkendaraan ataupun pada waktu hendak melewati kendaraan lain ataupun pada saat hendak berbelok arah; (4) pemberian hak utama untuk didahulukan kepada kendaraan bermotor tertentu atau kendaraan yang berasal dari arah tertentu ketika berada di persimpangan atau perlintasan.

Norma-norma UU LLAJ seperti diuraikan di atas menunjukkan adanya tingkat komprehensivitas yang tinggi dengan tingkat potensi dukungan yang tinggi pula bagi terciptanya KAMSELTIBCAR dan lebih lanjut pada upaya meminimalisir potensi kecelakaan lalu lintas. Namun persoalannya adalah : pertama, mampukah pesan norma beserta semangat yang terkandung di dalam UU tersebut dipahami secara tepat dan kemudian dijabarkan secara tepat pula ke dalam peraturan pelaksanaannya baik dalam peraturan pemerintah atau peraturan menteri atau peraturan kepolisian maupun dalam peraturan daerah. Artinya pembentukan peraturan pelaksanaan UU LLAJ harus mampu menjabarkan semangat di dalamnya dengan cara menjabarkan secara tepat dan menjaga konsistensi antara norma-normanya dengan tujuan KAMSELTIBCAR dan minimalisasi kecelakaan lalu lintas. Hal ini perlu diperhatikan sungguh-sungguh karena ada kecenderungan peraturan pelaksanaan dibuat dengan muatan kepentingan tambahan yang bertentangan dengan tujuan yang ditetapkan dalam Uunya;

Kedua, mampukah pesan norma beserta semangat yang sudah dirumuskan dalam UU LLAJ dipahami dan ditanamkan pada sikap dan perilaku para petugas yang memberikan pelayanan administratif pengujian dan pengawasan di jalan dengan sungguh-sungguh sesuai dengan norma dan semangat yang sudah diamanatkan dalam UU. Hal ini perlu 
diingatkan karena ada kecenderungan pola perilaku yang sudah terbentuk dalam pelayanan dan pengawasan yang bertentangan dengan semangat UU LLAJ akan sangat sulit diubah.

Ketiga, mampukah pesan norma beserta semangat menciptakan KAMSELTIBCAR dalam UU LLAJ dipahami dan ditanamkan sebagai sikap dan perilaku para pengguna jalan. Mampukah pesan UU ini tersosialisasi dan terinternalisasi dengan baik sehingga pengguna jalan yang sudah tertib semakin meningkat ketertibannya serta menjamin keamanan, keselamatan, dan kelancaran lalu lintas. Sebaliknya pengguna jalan yang masih berkendaraan tidak wajar dan ugal-ugalan dengan berbagai alasan apapun merubah perilakunya di jalan ke arah yang tertib. Hal ini perlu diingatkan karena perilaku tidak wajar dan ugal-ugalan kadang sulit diubah dan bahkan virusnya dengan sangat mudah menjalar pada pengemudi yang tertib menjadi ikut-ikutan tidak tertib.

\section{Kelembagaan Pelaksana}

Struktur kelembagaan pelaksana UU merupakan merupakan komponen sentral bagi efektivitas pencapaian tujuan. Kelembagaan beserta kelengkapan strukturnya merupakan motor penggerak pelaksanaan dari setiap UU. Komponen kelembagaan merupakan pengemudi/nakhoda ke arah tujuan manakah atau ke arah kondisi sosial seperti apakah pelaksanaan UU akan dibawa. Penataan struktur kelembagaan dan jaringan kinerjanya yang baik menjadi salah satu faktor utama yang ikut menentukan keberhasilan pelaksanaan UU dalam mewujudkan tujuan.

Terlepas dari dinamika mekanisme politik yang mewarnai proses pembentukannya, UU No.22 Tahun 2009 menorehkan suatu catatan monomental sebagai UU yang mampu melakukan penataan kelembagaan pelaksananya secara lintas sektoral. Persaingan kepentingan yang berlangsung antar sektor pemangku kepentingan selama proses politik harus ditempatkan sebagai bagian dari karakter demokratis dan kontraktual pembentukan UU No.22 Tahun 2009 sebagai hukum modern (Galantar, 1968). Namun dari kacamata akademis, produk UU LLAJ sebagai hasil dari proses politik tersebut harus dinilai sangat positif dalam penataan secara lintas sektoral kelembagaan pelaksana UU. Tidak banyak UU yang secara substansial menuntut peranan sejumlah lembaga sektoral secara bersamasama dapat menorehkan rumusan norma yang mengakomodasi kelembagaan secara lintas sektoral. UU LLAJ termasuk di antara undang-undang yang jumlahnya sangat sedikit atau bukan tidak mungkin sebagai satu-satunya undang-undang yang mampu mengakomodasi dan mengikutsertakan semua lembaga sektoral yang secara historis dan aktual memang ikut berperanan dalam lalu lintas dan angkutan jalan.

Secara das sollen, UU LLAJ sudah melakukan penataan kedudukan dan peranan departemen-departemen dan lembaga non departemen serta pemerintah daerah. Ada 3 (tiga) bentuk penataan yang sudah dinormakan yaitu :

a. Pendistribusian dan penegasan kewenangan yang sifatnya sektoral kepada masingmasing lembaga yaitu Departemen Perhubungan, Departemen Pekerjaan Umum, Kepolisian Negara Republik Indonesia, Departemen Perindustrian, dan Kementerian Riset dan Teknologi, serta pemerintah-pemerintah daerah.

b. Pembentukan Forum Lalu Lintas dan Angkutan Jalan baik di pusat maupun di daerah, yang akan berfungsi sebagai media kelembagaan terhadap pelaksanaan UU LLAJ yang memang harus dilakukan secara lintas sektoral. Di antaranya berkenaan dengan : perencanaan jaringan LLAJ, rencana tindaklanjut hasil uji kalaikan fungsi jalan, rekomendasi pemberian ijin oleh daerah untuk pendirian Bengkel Umum Kendaraan Bermotor, pelaksanaan pendidikan dan pelatihan mengemudi, manajemen dan 
rekayasa lalu lintas, penataan manajemen Sistem Administratif Manunggal Satu Atap di daerah, pelaksanaan pemeriksaan berkala kendaraan bermotor di jalan, penegakan hukum yang harus melibatkan penyidik kepolisian dan penyidik pegawai negeri sipil. Forum ini harus berfungsi sebagai ajang rembuk di antara lembaga-lembaga sektoral di atas untuk memadukan dan menserasikan kewenangan-kewenangannya. Tujuannya bukan untuk memaksimalkan kepentingannya masing-masing namun lebih ditujukan untuk mengoptimalkan pencapaian tujuan KAMSELTIBCAR dan tujuan akhir UU termasuk di dalamnya adalah minimalisasi kecelakaan dan kemungkinan pencapaian zero-accident.

c. Dorongan ke arah berlangsungnya koordinasi antara pusat dengan daerah sehingga ada keterpaduan pembinaan dan penyelenggaraan lalu lintas dan angkutan jalan antara yang dirancang oleh pusat dengan kondisi riil yang ada di masing-masing daerah. Ruang LLAJ bukanlah wilayah yang dapat sepenuhnya dibagi ke dalam ruang administratif masing-masing daerah dan pusat. Ruang LLAJ merupakan satu kesatuan sistem yang perencanaan, pelaksanaan, pengawasan, dan evaluasinya harus dilakukan secara terkoordinasi antara pusat dengan daerah.

Persoalannya, mampukah ketiga penataan kelembagaan di atas terimplementasi secara kongkret. Dasar penataan kelembagaan yang mampu secara efektif berperanan mewujudkan tujuan UU LLAJ sudah diletakkan. Namun pelaksanaannya sepenuhnya tergantung pada manusia-manusia yang berkedudukan sebagai pelaksana kewenangan kelembagaan untuk : Pertama, memegang teguh amanat penataan kelembagaan yang sudah ditetapkan dalam UU dengan cara melaksanakan secara sungguh-sungguh amanat tersebut; Kedua, pelaksanaan baik kewenangan sektoralnya maupun kewenangan yang harus dilaksanakan lintas sektor atau secara koordinatif pusat-daerah harus diorientasikan pada pencapaian tujuan UU. Ukuran keberhasilan pelaksanaan tugas sektor ataupun lintas sektor ataupun lintas pusat-daerah adalah kemampuan mewujudkan tujuan UU yaitu KAMSELTIBCAR dan tujuan akhir seperti kesejahteraan masyarakat secara immateriil dalam bentuk terhindar dari terjadinya kecelakaan lalu lintas.

\section{Budaya Hukum}

Budaya hukum bukan hanya sekedar komponen utama sistem hukum namun juga menjadi faktor dasar terpenting bagi upaya mewujudkan tujuan UU. Budaya hukum mengandung nilai sosial yang menjadi dasar dan pendorong utama perilaku hukum setiap orang dalam berlalu lintas. Budaya hukum yang menentukan tingkat kepatuhan para pengguna jalan serta petugas lalu lintas dan pelayanan administratif. Untuk itu, ketentuan-ketentuan UU LLAJ yang sudah komprehensif dan potensi dukungan terhadap pencapaian tujuan yang sudah sedemikian tinggi harus dapat tersosialisasi dan terinternalisasi menjadi sikap dan perilaku dari setiap pengguna jalan dan petugas. Semakin tinggi tingkat pemahaman masyarakat dan semakin mendalam internalisasi norma dalam sikap dan perilaku, maka semakin terbentuk budaya hukum.

Karena budaya hukum merupakan faktor utama dan dasar, maka penanaman norma-norma UU LLAJ menuntut perubahan nilai sosial atau perubahan sikap dan perilaku dari yang lama ke yang baru. Artinya perlu pembentukan budaya hukum baru berkenaan dengan sikap dan perilaku berlalu lintas. Ada 2 (dua) lingkungan budaya yang harus diupayakan terbentuk, yaitu: 


\section{Budaya hukum berlalu lintas pengguna jalan}

Di antara kelompok-kelompok pengguna jalan terutama pada saat berlalu lintas masih mengembangkan budaya hukum yang tidak sejalan dengan tujuan menciptakan KAMSELTIBCAR dan minimalisasi terjadinya kecelakaan dan korban manusia. Budaya hukum yang tidak sejalan itu ditunjukkan oleh sikap dan perilaku yang menempatkan : jalan sebagai milik pribadi sehingga memaksa pengguna jalan lainnya harus menyingkir atau menepi ketika syang pemilik sedang lewat serta berhenti di sembarang tempat dengan mendatangkan bahaya dan ketidaknyamanan bagi yang lain, jalan sebagai sarana unjuk diri sebagai manusia yang paling terampil berkendaraan dengan mengendarai/mengemudi kendaraan bermotor secara ugal-ugalan, berkendaraan bermotor di jalan sebagai media ekonomi untuk mengoptimalkan pendapatan dengan cara mengeksploitasi diri seperti yang ditampilkan oleh pengemudi angkutan umum atau dengan cara mengeksploitasi orang lain seperti yang diterapkan perusahaan angkutan umum terhadap para sopir, berkendaraan bermotor di jalan umum yang menimbulkan ketidaknyamanan orang dan bahkan mengancam keselamatan orang lain. Nilai yang berkembang bahwa berkendaraan secepatcepatnya cerminan kemajuan dan pelan-pelan asal selamat cerminan ketradisionalan.

Budaya hukum konfrontatif seperti di atas harus diubah ke arah budaya hukum konformatif, yaitu penanaman sikap dan perilaku yang mendukung KAMSELTIBCAR dan minimalisasi kecelakaan dan korban nyawa manusia. Perubahan sikap dan perilaku yang dikehendaki adalah jalan bukanlah arena berlangsungnya killing field, jalan bukanlah sarana ugal-ugalan berkendaraan, jalan bukanlah arena unjuk "inilah daku sebagai orang yang paling terampil berkendaraan". Berlalu lintas di jalan bukanlah hanya sekedar mematuhi rambu/marka/APIL/petugas namun harus mendasarkan pada etika moral berlalu lintas berupa sikap saling menghormati sesama pemakai jalan, sikap dan perilaku untuk tidak menyakiti perasaan sesama pengguna jalan, sikap dan perilaku yang menempatkan ruang lalu lintas sebagai ruang umum/publik di mana kita tidak boleh berperilaku sekehendak keinginan kita, ruang lalu lintas bukan ruang pribadi yang dapat berperilaku sekehendak keinginan kita, sikap dan perilaku kita berlalu lintas tidak boleh menempatkan pengguna jalan yang lain berada dalam kondisi ketidaknyamanan/ kekagetan luar biasa. Nilai yang sudah tertanam bahwa berkendaraan lebih cepat lebih baik harus diubah dengan "biar tidak terlalu cepat namun yang penting aman dan selamat".

Upaya melakukan perubahan dari budaya konfrontatif menjadi konformatif memang tidak mudah, namun harus dilakukan secara bertahap.

\section{Budaya hukum kinerja kelembagaan}

Budaya hukum konfrontatif dalam kinerja kelembagaan petugas lalu lintas dan angkutan jalan masih berlangsung, meskipun tingkatannya pada oknum petugas. Meskipun demikian, konsekuensinya tetap memunculkan penilaian negatif terhadap citra kelembagaan. Budaya konfrontatif ditunjukkan oleh masih berlangsungnya, yaitu : (1) sikap dan perilaku grafitikatif (penyuapan) dalam pemberian pelayanan perijinan (SIM atau Trayek) dan pengujian kendaraan. Budaya gratifikatif ini cenderung berkonsekuensi pada pengabaian terhadap kualitas dan persyaratan perolehan ijin dan pelulusan uji kendaraan bermotor yang ditetapkan untuk menjamin kemampuan dan kematangan jiwa pemegang SIM, pengabaian terhadap dampak pemberian ijin trayek terhadap tingkat kepadatan lalu lintas yang berpotensi pada terjadinya kecelakaan, pengabaian terhadap persyaratan teknis dan kelaikan jalan kendaraan bermotor; (2) sikap dan perilaku kekuasaan atau kewenangan merupakan milik pribadi yang harus digunakan untuk 
maksimalisasi kepentingan diri. Penindakan atas pelanggaran yang terjadi cenderung kompromistik. Akibatnya terjadi pengabaian terhadap upaya membangun kejeraan dan kesadaran berlalu lintas masyarakat yang baik, pengabaian terhadap kerusakan jalan yang berpotensi kelaikan fungsi jalan menurun dan akan menjadi penyebab kecelakaan, serta pembiaran dan pemberian legitimasi terhadap pelanggaran yang justeru mendorong ke arah terjadinya kecelakaan. Untuk mengubah budaya konfrontatif menjadi budaya konformatif, perlu dikembangkan sikap dan perilaku kinerja yang : (1) menempatkan pelayanan bukan sebagai transaksi namun sebagai bentuk upaya pengayoman kepada masyarakat, optimalisasi kepuasan masyarakat, dan pembangunan kesadaran hukum berlalu lintas yang baik; (2) menempatkan kewenangan atau kekuasaan sebagai amanah publik yang harus dilaksanakan untuk optimalisasi kepentingan publik yaitu penanaman nilai etika moral berlalu lintas dan bukan untuk kepentingan diri sendiri. Penindakan atas pelanggaran harus ditujukan membangun kejeraan tidak mengulang pelanggaran.

Ada 2 (dua) pendekatan yang harus digunakan untuk membangun budaya konformatif baik di lingkungan pengguna jalan dan petugas lalu lintas, yaitu : Pertama, pendekatan kontrol sosial baik formal maupun informal untuk membentuk tingkat kepatuhan hukum dari yang paling rendah yaitu complience sampai yang paling tinggi legal conscieseness. Complience merupakan suatu tingkatan kepatuhan hukum yang didorong oleh adanya pengawasan secara terus-menerus oleh aparat/petugas atau oleh atasan, sedangkan legal consciesness merupakan tingkatan kepatuhan hukum yang didorong oleh hati nuraninya sendiri dan perasaan bersalah pada diri sendiri; Kedua, pendekatan keagamaan dengan cara menanamkan suatu keyakinan bahwa berlalu lintas yang baik atau memberikan pelayanan dan pengayoman kepada masyarakat merupakan bagian satu bentuk ibadah yang punya konsekuensi horizontal dan vertikal.

\section{DAFTAR PUSTAKA}

Satjipto Rahardjo, 1989, Hukum dan Perubahan Sosial, penerbit Alumni, Bandung, halaman

Sudikno Mertokusumo, 1999, Mengenal Hukum, Suatu Pengantar, Penerbit Liberty, Yogyakarta, halaman 16-17

Lawrence M. Friedman, 1975, The Legal System, A Social Science Perspective, Russell Sage Foundation, New York, halaman 11 - 16

Mac Galantar, 1968, The Modernization of Law, dalam Myron Weiner : Modernization : Dynamic of Growth, Basic Book Inc., New York, halaman 154-156 